Article

\title{
Election Reform and Women's Representation: Ranked Choice Voting in the U.S.
}

\author{
Cynthia Richie Terrell *, Courtney Lamendola and Maura Reilly \\ RepresentWomen, Takoma Park, MD 20912, USA; E-Mails: cynthiarichieterrell@representwomen.org (C.R.T.), \\ courtneylamendola@representwomen.org (C.L.), maurareilly@representwomen.org (M.R.) \\ * Corresponding author
}

Submitted: 14 December 2020 | Accepted: 21 April 2021 | Published: 15 June 2021

\begin{abstract}
Ranked choice voting first gained a foothold in the U.S. during the Progressive movement in the 20th century as calls for electoral reforms grew. Ranked choice voting was implemented in many cities across the U.S. in both single- and multi-seat districts. But, by the 1940s it became a victim of its own success, turning the tides of the hegemonic white male leadership in U.S. legislative bodies with the election of women. Since the 1990s, ranked choice voting has once again gained traction in the U.S., this time with the focus on implementing single seat ranked choice voting. This article will build on the existing literature by filling in the gaps on how ranked choice voting -in both forms-has impacted women's representation both historically and in currently elected bodies in the U.S.
\end{abstract}

\section{Keywords}

descriptive representation; electoral reform; fair representation voting; progressive movement; proportional representation; ranked choice voting; single transferable vote; women's representation

Issue

This article is part of the issue "The Politics, Promise and Peril of Ranked Choice Voting" edited by Caroline Tolbert (University of lowa, USA).

(C) 2021 by the authors; licensee Cogitatio (Lisbon, Portugal). This article is licensed under a Creative Commons Attribution 4.0 International License (CC BY).

\section{Introduction: Electoral Systems Matter}

At the start of the 20th century, reformers who made up the Progressive movement pushed against the status quo in American society. Along with advocating for child-labor laws and anti-monopoly legislation, the movement took on expanding the electorate and addressing the corruption rife within American politics. As many progressive reforms were adopted in the U.S., including the direct election of the U.S. Senate, open-primaries, homerule municipal charters, and the expansion of suffrage to women, in response, reformers then looked to implement an electoral system that would address the widespread corruption within American politics (Novoselic, 2015).

Electoral reform groups at the time pointed to the U.S.' winner-take-all electoral system, which often resulted in plurality winners, party supermajorities, and the stranglehold of political machines and party bosses as a root cause of the obstacles facing the U.S. reform groups backed an electoral system that results in proportional representation for voters while preserving the one vote per person tenet; in particular the adoption of ranked choice voting with multi-seat districts, alternatively known as the single transferable vote or proportional ranked choice voting (Amy, 1996).

Proponents for replacing the winner-take-all electoral system with a proportional system included many women's suffrage organizations that looked to expand their electoral voice and improve women's representation after the passage of the 19th Amendment. The National League of Women Voters along with many local leagues across the country were drafted into the cause for single transferable voting during the 1920s (Barber, 2000, p. 45). Along with improving the electoral chances for independent candidates, single transferable voting circumvented the control political machines had 
on local elections and elected officials; political machines that openly opposed extending women the right to vote just a few years prior (Barber, 2000, p. 44). This adversarial relationship encouraged many suffragists to focus their energy and influence on promoting reforms to undermine the power of political machines and party bosses. With growing support from the Progressive movement and expanding interest among women and other citizens typically excluded from elected office, ranked choice voting was primed to sweep the country in the first half of the 20th century.

Along with addressing the growing corruption in U.S. politics, jurisdictions using the single transferable vote also witnessed the growing elected representation of women, minority communities and third parties all of which remained largely stagnant nationally. Now, a century later, the U.S. continues to face the systemic underrepresentation of women and minority groups due in no small part to the continued use of an antiquated electoral system. The solution remains the same, ranked choice voting.

\section{Literature Review}

\subsection{The Underrepresentation of Women in Government}

The underrepresentation of women in government is well-documented by existing literature (Center for American Women and Politics, 2021; Dittmar, 2020; Lamendola \& Terrell, 2020a). However, most scholars of American politics have tended to focus on the individuallevel experiences of women as prospective candidates. Until recently, a leading explanation for the underrepresentation of women in government was that women were less likely to run for political office than men. The most prominent scholarship behind this explanation put forward the idea that women lack political ambition (Lawless \& Fox, 2005).

In the study of gender dynamics in U.S. politics, scholars have found ample evidence that women and men have different experiences running for elected office, from the decision to run, to the dynamics on the campaign trail, to the votes cast on election day (Fox, 1997). And while more recent scholarship in the U.S. has remained overwhelmingly candidate-centered, some researchers have gone on to explore society's expectations of politicians and whether women face an unfair 'double-bind' as aspiring candidates (Teele, Kalla, \& Rosenbluth, 2018). Other scholars have since explored whether gendered occupational pathways to power have an even larger role in determining who runs for office in the first place (Thomsen \& King, 2020).

Scholars of comparative politics, on the other hand, have been more likely to research the structural and institutional factors of gender-based representation, including election system design, gender quotas, and the incumbency advantage (Piscopo, 2020; Piscopo, Krook, \& Franceschet, 2012; Rule, 1987, 1994; Thomas \& Wilcox,
2012). According to Wilma Rule (1987), election system design is one of the most significant predictors of women's recruitment and electoral success. Previous research conducted by our team further indicates that women's representation around the world varies considerably, depending on the election system used (Terrell \& Reilly, 2020a).

Other research has been conducted on gender politics in the U.S. looking into the political party dynamics which accompany the rise in women candidates, emphasis placed on 'women's issues,' and the difference in legislation supported by women versus men legislators (Osborn, 2012; Wolbrecht, 2000). While the impact women have on U.S. political culture and the legislative landscape is an important topic for future studies, this article focuses on institutions and barriers women face running for office in the U.S. rather than the impact they may have once elected.

\subsection{The Impact of Ranked Choice Voting on Representation}

The existing literature on ranked choice voting tends to fall into one of three major categories: research on proportional ranked choice voting between the 1910s and 1960s (Amy, 1996; Burnham, 1997, 2013; Kolesar, 1996); the modern resurgence of single- and multi-seat ranked choice voting in the U.S. since the 1990s (Richie, 2004); and the prevalence of similar 'preferential' voting systems in different parts of the globe (Bennett \& Lundie, 2007; Reilly, 2002; Schwindt-Bayer, Malecki, \& Crisp, 2010).

Key findings from this literature include evidence that ranked choice voting promotes cooperation among rivals (Reilly, 2002), rewards campaign civility (Amy, 1996; Donovan, Tolbert, \& Gracey, 2016; McGinn, 2020), promotes greater voter satisfaction (Donovan et al., 2016), and improves political legitimacy (Anest, 2009). Each of these elements is important for improving women's representation in the U.S., where negative campaigning might otherwise discourage women from running in the first place (John, Smith, \& Zach, 2018; Lamendola \& Terrell, 2020b).

While there is evidence of women and minorities achieving greater political representation when proportional ranked choice voting was in use throughout the early 1900s (Amy, 1996; Kolesar, 1996), less work has been done to assess how well women have fared in recent ranked choice elections. One of the most notable exceptions to this includes research by John et al. (2018), which found that representation increased for womenand minority women, in particular-in the single-winner ranked choice elections that took place in the California Bay Area in the 2000s.

\subsection{Our Contributions to the Literature}

While the first half of this article reviews the history of proportional ranked choice voting in the U.S. between 
1915 and 1962, the second half of the article presents our original research on single- and multi-seat ranked choice voting since its resurgence after the turn of the century. The data tracks outcomes for women and men in 19 U.S. cities that used single- and multi-seat ranked choice voting between 2010 and 2019, building on previous research conducted by our team in 2016 on the emergence of single-seat ranked choice voting in the California Bay Area in the early 2000s.

\subsubsection{A Note on the Terms Used in This Article}

In the following article, unless otherwise noted, 'proportional ranked choice voting' specifically refers to a system in which voters rank candidates in order of preference and multiple winners are selected using a round-by-round vote-counting process. Elsewhere, this system may be referred to as the 'single transferable vote,' 'fair representation voting,' or simply 'proportional representation.'

Proportional ranked choice voting should not be conflated with the single-seat variant, in which voters rank candidates in order of preference and a round-by-round vote-counting process ensues until a candidate secures majority support and is determined the sole winner. Elsewhere, this system may be referred to as 'instant runoff voting,' 'the alternative vote,' or 'majority preferential voting.' Variations in ranked systems, also known as 'preferential voting' and 'transferable voting' systems more generally, may occur if a different number of candidates are ranked on a ballot or if another counting system is used to determine the winner.

\subsection{Gaps in the Literature Not Covered}

The existing literature on women's representation in American politics and the impact of ranked choice voting on minority representation is robust, but rarely overlaps. And while the following article outlines some of our findings and core arguments for adopting proportional ranked choice voting nationwide, we also recognize the natural limitations of applied research, and invite others to continue this work. One of the greatest barriers to this work has been the relative lack of data on representation at the local level, which makes it difficult to assess how large a role election system design has had on women's representation in ranked choice cities.

An important contribution to this work has come from the MGGG Redistricting Lab, which recently released a report (Benade, Buck, Duchin, Gold, \& Weighill, in press) that presents a data-driven approach for assessing the likely impact of proportional ranked choice voting on minority representation-particularly in cities that have experienced Voting Rights Act legal challenges in the last decade. As we wait for more data to become available from the cities using single- and multi-seat ranked choice voting today, making use of predictive models like this may be a useful way of expanding the available lit- erature, especially if they can be adapted to assess the impact of ranked choice elections on women candidates.

\subsection{History of Ranked Choice Voting in the U.S.}

Cities that adopted ranked choice voting in the early 20th century illustrated the effectiveness of the system for improving representation of minority groups, women, and small parties often shut out of government through the winner-take-all system previously in effect. Unfortunately, it is the successes of descriptive representation, negative reactions to the growing diversity in local government, and fears stoked by Cold War tensions that ultimately helped to "push repeal initiatives over the top" (Barber, 2000, p. 148).

The many successes of proportional ranked choice voting in the 20th century-removing corrupt party bosses from office, reducing the power political machines had over election outcomes, and improving descriptive representation-led to organized and divisive repeal campaigns across the U.S. Politicians and parties that saw their power and privilege decline during the proportional period preyed "upon two of the most basic fears of white, middle class Americans: Communists and African-Americans" and launched a series of successful repeal campaigns from New York to Ohio (Amy, 1996, p. 18). And, by 1962, Cambridge, Massachusetts remained the only jurisdiction continuing to use ranked choice voting in the U.S.

Despite the divisive repeal campaigns, women's representation and political power often grew during the tenure of proportional ranked choice voting in New York City and several Ohio cities. Even in cities that did not see a substantial uptick in women's elected representation, women's organizations, including local chapters of the League of Women Voters, were often the last-standing supporters of the proportional representation system. Historically, ranked choice voting in the U.S. has been supported by women fighting to correct the homogeneity of the elected officials and can be built upon in the present day to achieve gender balanced representation.

\subsubsection{Proportional Representation Sweeps Ohio: 1915-1926}

In 1912, the Ohio state legislature passed an amendment to the state's constitution allowing for "home rule," enabling cities to choose their form of government and electoral system (Supreme Court of Ohio, 1912). Following the amendment, several cities in Ohio implemented electoral reforms including the adoption of ranked choice voting in at-large and multi-seat districts by four cities.

Ashtabula adopted the single transferable vote in 1915 , becoming not only the first city in Ohio to implement proportional representation but also the first city in the entirety of the U.S. (Barber, 1995, p. 83). Following the first election using single transferable voting in 
Ashtabula, local reporters commented on the increased ideological, religious, and ethnic diversity of the winning candidates compared to previous city council elections. One such reporter noted: "The drys and the wets are represented; the Protestants and Catholics; the business, professional, and laboring men; Republicans, Democrats, Socialists; the English, Swedes, and Italians are represented" (Amy, 1993, p. 10). While not a highlighted part of the new diversity of Ashtabula's elected officials, proportional ranked choice voting also impacted women's representation in other cities that followed suit and adopted the electoral system.

Cleveland's adoption of the single transferable vote provides a clearer example of the impact the voting system could have on women's descriptive representation. Cleveland followed Ashtabula's example adopting proportional ranked choice voting in 1923. Women's representation on Cleveland's city council improved during the eight years single transferable voting was used. Between 1923 and 1931, eight women were elected to the council, while none were elected in the three elections prior to 1923 (Barber, 1995, p. 139). As women won the right to vote and political say grew, so too did their electoral representation under the new proportional system, a jump in representation not seen universally across the U.S.

In 1925, following a concerted and organized petition campaign led largely by the Woman's City Club, a reform charter was put on the ballot in Hamilton, Ohio. The overwhelming support for the measure resulted in the creation of the Hamilton Charter Commission which recommended the use of single transferable voting already being used in several Ohio cities (Barber, 2000, p. 107). In 1927, Hamilton had their first city-wide elections using the proportional representation system; an election noted for change, only two incumbent city council members won reelection (Barber, 1995, p. 215). The system addressed the incumbent advantage which often reinforces the homogeneity of elected officials and hurts the chances of political newcomers, more likely to be women.

As in many Ohio cities at the time, the single transferable vote resulted in many electoral firsts for traditionally underrepresented groups. In 1943, E. W. Frechtling became the first woman elected to the Hamilton city council. Although she ran in 1943 with her initials, in 1945 she won reelection with her full name Eleanore Frechtling listed on the ballot (Barber, 1995, p. 223).

Before the eventual repeal of single transferable voting in 1960, Hamilton saw three failed repeal attempts. The first two, in 1929 and 1933 were both spearheaded by the old Democratic Party machine which had dominated Hamilton elections prior to the implementation of ranked choice voting (Barber, 1995, p. 231). The 1944 repeal effort focused instead on World War II sentiments of patriotism, branding the single transferable vote as 'un-American.'

Despite the opposition, proponents of single transferable voting, once again led by the Woman's City Club, successfully made the case for the proportional voting system, arguing it allowed underrepresented groups to have fair representation on the council (Barber, 1995, p. 233). In 1960, with the majority of other Ohio cities having already repealed their proportional electoral systems and support from the AFL-CIO, which had opted to remain neutral during previous repeal attempts, Hamilton opponents to proportional representation successfully repealed the system.

In 1934, Toledo became the last Ohio city to adopt single transferable voting. Toledo is an often-overlooked example of early use of ranked choice voting due in part to the time lag between implementation and the resulting descriptive representation. No women were elected to the Toledo City Council during or before the implementation of single transferable voting, despite women's groups being some of the most vocal supporters of the system. It would not be until 1960 that a woman was finally elected to the council (Barber, 1995, p. 267). Despite women not seeing electoral advances in Toledo, proponents of the voting system were led largely by the Toleda League of Women Voters.

During the 15 years proportional representation was used in Toledo, opponents launched five repeal campaigns, finally succeeding in 1949 (Barber, 1995, p. 252). By the fifth repeal attempt, the Toledo League of Women Voters remained the sole organization continuing to support single transferable voting, arguing the proportional system was better at giving a voice and allowing the representation of un-represented groups including women and African-Americans.

\subsubsection{Proportional Representation in New York City}

Progressive reformers of the early 20th century were particularly interested in reforming rampant political corruption including party machine political dominance, and partisan skews found in many city councils at the timepolitical corruption perhaps best illustrated by Tammany Hall and New York City's Board of Aldermen.

During the 1920s and 1930s the New York City Board of Aldermen, a precursor to the current City Council, was dominated by Democratic supermajorities due in no small part to the electoral stranglehold the Democratic political machine Tammany Hall had over votes and the electoral system that resulted in disproportionate seat bonuses. Following political scandals involving the Democratic Party and Tammany Hall during the early 1930s, electoral reform measures adopted in 1936 included the adoption of proportional representation to elect the Board of Aldermen to limit the power Tammany Hall had over New York City politics. With the specific adoption of the single transferable vote, the system was perfectly set up to ensure "a mix of local representation, minority representation, and third party representation that New York had never seen before" (Doctor \& Landsman, 2017, p. 5).

The introduction of single transferable voting led to the election of the first woman and the first African- 
American man to the Board of Aldermen. In 1937, after serving as the only woman on the city's Charter Revision Committee, Genevieve Beavers Earle became the first woman on the Board of Aldermen. In 1941 Earles was joined by Adam Clayton Powell Jr. the first African-American man elected to the Board (Ochoa \& Cheung, 2020).

In 1947, after 10 years of the single transferable vote, the coordinated assault on the system finally won out, and ranked choice voting was removed in favor of a winner-take-all, plurality system. Popularity for repeal grew among the Republican Party, who began to see their share of seats go down as vote shares for third parties grew. Additionally, Democratic realignment around FDR and the popularity of the New Deal minimized many of the reasons reform went on the ballot a decade earlier (Doctor \& Landsman, 2017, pp. 18-19). However, the rising tensions of the Cold War and the ensuing Red Scare allowed opponents of proportional representation to successfully exploit the election of Communist Party candidates, which started with the implementation of single transferable voting (Amy, 1996).

\section{Ranked Choice Voting Theory on Improving Descriptive Representation}

In U.S. politics incumbents receive many advantages when it comes to running for office that in turn create structural barriers for political newcomers, who are more likely to be women or from other traditionally underrepresented communities. While this article focuses on the impact ranked choice voting has had on women's representation in the U.S., many of the ways ranked choice voting impacts the barriers for political newcomers would likely help the electoral representation for people of color as well as women.

There is a common refrain in U.S. politics that 'when women run, women win.' These words echo a perception held by activists and political scientists alike that the underrepresentation of women in politics is a pipeline problem, rather than a structural problem. What proponents of this refrain often miss is the importance of 'seat type' for women's representation. During both the 2018 and 2020 U.S. Congressional elections, which were widely held up as 'record-breaking' years for women candidates, women still had substantially lower success rates than men, as the majority of new women candidates ran as challengers, instead of in open-seat races, where women fared better. In 2018, the men who ran for Congress had a success rate of $54 \%$; the success rate for women candidates was lower at $44 \%$. In 2020, there was an even larger gap in success rates, with men winning $50 \%$ of their races and women only winning $36 \%$.

A 2010 study found that "if women are not recruited to fill open seats, then the power of incumbency will continue to inhibit their numeric representation" (Fox \& Lawless, 2010, p. 311). When controlled for seat type men and women often have comparable success rates at least at the national level in the U.S. However, as men continue to make up the majority of incumbents, efforts to increase women's representation solely by recruiting more women to run for office fall short of achieving transformative growth.

Just as candidate-focused solutions alone will not be enough to achieve parity in the U.S., this is not all to say that women's equal political representation will be achieved simply through the implementation of ranked choice voting and other structural reforms. To achieve parity in the U.S., advocates will need to pursue both structural and candidate-focused interventions. Since women have been filing to run as challengers in greater numbers over the last few years, interventions that stand to mitigate the barriers that challengers face will become necessary. Previous research on ranked choice voting has illustrated that the adoption of a new electoral system may help to mitigate the barriers that non-incumbents face. Specific barriers that ranked choice voting has the potential to address include the spoiler effect (Amy, 1993; Zimmerman, 1994), high campaign costs, and negative campaign tactics (Donovan et al., 2016).

\subsection{The Spoiler Effect}

The U.S.' favored single-winner, plurality electoral system is vulnerable to the spoiler effect, especially when there is a large field of candidates. The spoiler effect restricts healthy competition, especially during primaries, and strengthens the power of political gatekeepers to use the spoiler effect as a reason to limit opportunities for political newcomers.

Although the spoiler effect impacts both male and female candidates, women and women of color in particular are more often told to "wait their turn" before running for office (Malveaux, 2018). A 2020 study found Black women vying for elected office in the U.S. faced many structural barriers to becoming candidates, "Noting issues ranging from perceived lack of electability to be told to 'wait their turn,' " by party leaders and gatekeepers (Brown \& Lemi, 2020, p. 1633). Similar situations have been anecdotally reported by women of all races.

Comparable scrutiny and gatekeeping is not often seen when more than one white male candidate is running for a seat, as they are typically seen as the norm. When discussing identity politics, the "political status quo is treated as race-neutral, when it is in fact anything but" (Sellers, 2019, p. 1515). Similar trends can be seen when discussing gender in U.S. politics, with structural barriers being cast as gender neutral, when in reality they advantage male candidates by default.

Ranked choice voting in single-seat districts ensures no candidate wins with less than a majority of votes, $(50 \%+1)$ eliminating the threat of the spoiler effect, and depriving many political gatekeepers of their reason to only recruit one woman or person of color to run at a time. And, ranked choice voting in multi-seat districts has 
been shown to make voters more likely to balance their tickets and vote for both men and women candidates, encouraging parties to recruit more women (Amy, 1993; Zimmerman, 1994).

The first step to ensuring more women win elected office is increasing the number of women who run, ranked choice voting offers incentive for this to happen.

\subsection{The Cost of Successful Campaigns}

The cost of running campaigns in the U.S. is often commented on, with the amount of money raised and spent on Congressional campaigns growing every cycle. While there remains debate around the impact money has on outcomes and success rates, the cost of running a campaign can be daunting to political newcomers. Candidates running in open seats and as challengers are more likely to run with smaller donor networks and as a result often raise less money on average than incumbents (Terrell \& Reilly, 2020b, p. 31).

Ranked choice voting typically rewards a positive and issue-focused campaign, which lowers the cost of running. Because women are more likely to be running as challengers or in open seats, the more affordable grassroots campaigning encouraged by ranked choice voting and elimination of costly elections allows women to compete on a more level playing field (Lamendola \& Terrell, 2020b, p. 22).

\subsection{The Negative Campaign Style}

Together with increasing political polarization and partisanship are the negative campaign strategies that serve to alienate opponents in the hopes of ensuring base support. While many critics blame candidates and media sensationalism for the increasingly negative political environment, an often-overlooked contributor is the U.S.'s electoral system.

The winner-take-all plurality voting system currently used in the U.S. encourages personal appeals and character attacks to win, rather than the issue-focused arguments emphasized in ranked choice voting. Winning in the current system rests on a candidate's ability to please the most people for the most time, leading candidates to shy away from policy stances that may alienate supporters (Amy, 1993, pp. 63-66).

This system incentivizes campaigns to cast their opponents with negatively perceived qualities and characteristics to either garner more support from the base or lower turnout for their opponents. In turn, creating a political environment in which "one major reason candidates avoid confronting issues in campaigns is because it is the safest and most effective way to get elected under plurality rules" (Amy, 1993, p. 66). And although negativity in campaigns is often an issue faced by candidates of all genders, studies on the dearth of women candidates cite negative campaigns as a contributing cause (Thomas \& Wilcox, 2014, p. 7).
In ranked choice elections, candidates must campaign for not only first-choice votes but also second- and third-choice votes, encouraging coalition building rather than personal attacks (Donovan et al., 2016; Reilly, 2002). The grassroots campaign style favored in ranked choice elections encourages candidates to focus on policy goals and the issues facing their potential constituents rather than attacking their opponents' character. The emphasis placed on positive campaigns may encourage more women to run in ranked choice elections.

\section{Ranked Choice Voting in America Now}

\subsection{Ranked Choice Voting Returns}

Following a narrowly defeated 1991 referendum to reimplement ranked choice voting in Cincinnati, four electoral reform organizations across the U.S. formed the Citizens for Proportional Representation. Recognizing the need for an organized and concerted nationwide approach to electoral reform, Citizens for Proportional Representation took up permanent offices in Takoma Park, Maryland and changed their name to the Center for Voting and Democracy (Thomas, 2017). In the ensuing decades, the organization changed its name to FairVote and took on advocating for ranked choice voting up and down the ballot.

Since 1991 numerous U.S. cities and jurisdictions have adopted and implemented ranked choice voting in various capacities. Currently, more than 10 million voting age adults in 21 jurisdictions across 12 states use ranked choice voting, and an additional six states use ranked ballots for military and overseas voting. A growing number of Republican and Democratic state parties used ranked choice voting for internal elections in 2020 and the majority of states have pro-ranked choice voting organizations and pending ranked choice voting legislation. After re-adopting ranked choice voting via a ballot measure in 2019, New York City implemented ranked choice voting with a special election in February 2021, nearly doubling the number of voters using the electoral system.

During the 2018 midterm elections, Maine became the first U.S. state to use ranked choice voting in their federal elections to elect the representative for Maine's second Congressional district. In November 2020, the state made history once again using ranked choice voting for the presidential election and a highly contested U.S. Senate seat. Also on Election Day 2020, the state of Alaska and five other jurisdictions voted to adopt ranked choice voting, including: Boulder, Colorado; Minnetonka, Minnesota; Bloomington, Minnesota; Albany, California; and Eureka, California. In fact, only one of the ballot measures to adopt ranked choice voting failed this election cycle, a measure to adopt ranked choice voting for statewide elections in Massachusetts. 


\subsection{Ranked Choice Voting and Women's Political Representation}

\subsubsection{Methodology}

The 2016 study analyzes the impact of single seat ranked choice voting on women's representation in electoral contests from eleven California cities, including four cities that use ranked choice voting and seven control cities that did not adopt ranked choice voting. The control cities Alameda, Anaheim, Richmond, San Jose, Santa Ana, Santa Clara and Stockton were selected to reflect the demographics of the ranked choice voting treatment cities of Berkeley, Oakland, San Francisco and San Leandro (John et al., 2016).

Original 2020 research on ranked choice voting analyzes the demographics of candidates and winners in single- and multi-seat ranked choice elections with three or more candidates in the running between 2010 and 2019. Follow up research on women's representation in Bay Area municipalities using ranked choice voting was also conducted. This follow-up research includes a comparative analysis of women's representation in the four Bay Area cities using ranked choice voting, with California cities with a population of 30,000 or more, and the seven Bay Area control cities that have not adopted ranked choice voting (Lamendola \& Terrell, 2020b).

Due to the multiple factors affecting local election outcomes, this analysis does not infer causality between ranked choice voting and improvements in the descriptive representation, but instead illustrates the correlation. Other factors that could have influenced the elected rep- resentation include the increased reach of recruitment and training organizations focused on women candidates and an overall national trend of more women winning elected office. However, comparative analysis illustrates the number of women running for and winning elected office is higher in municipalities using ranked choice voting than in those using other voting systems.

\subsubsection{Women's and Minority Representation in the Bay Area}

Research on California Bay Area cities that used ranked choice voting for local elections, including city council and mayoral elections, found from analyzing outcomes pre- and post-ranked choice voting the number of women running for and winning local office increased compared to the control cities.

The percentage of women candidates went down in both the treated and control cities. However, the drop in women candidates was steeper in cities which did not use ranked choice voting suggesting ranked choice voting helped curb a larger trend occurring in the Bay Area (Figure 1).

Outcomes for women improved under ranked choice voting in the Bay Area. The percentage of women winning rose by two points. This slight increase is starker when compared to control cities that saw the percentage of women winning decrease by four and a half points during the same time period (Figure 2).

Follow up research on the 2016 report found in the Bay Area treatment cities women have won $56 \%$ of ranked choice elections between 2010 and 2019,

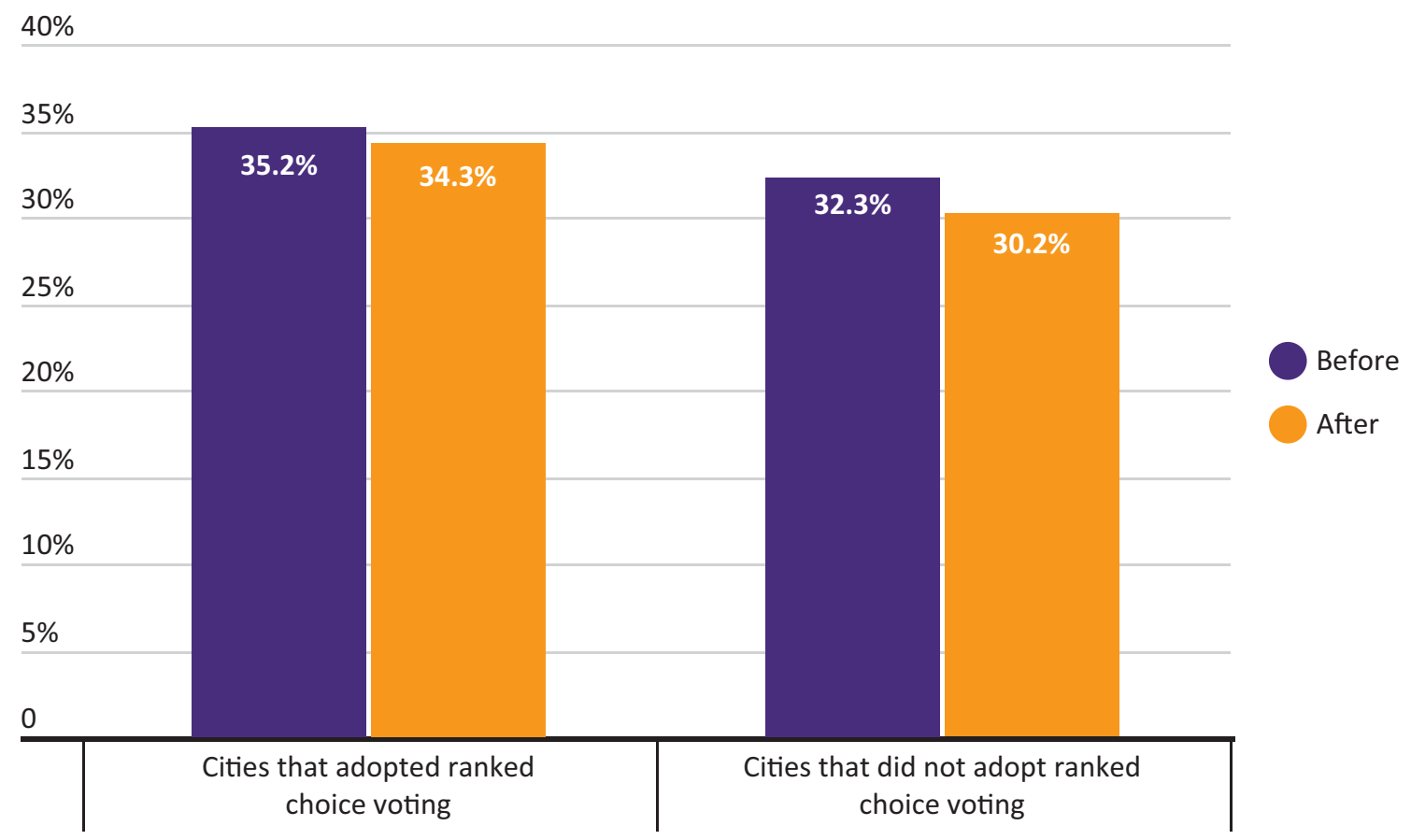

Figure 1. Percentage of women candidates, before and after ranked choice voting in the Bay Area (1995-2014). Source: John et al. (2016). 


\section{COGITATIO}

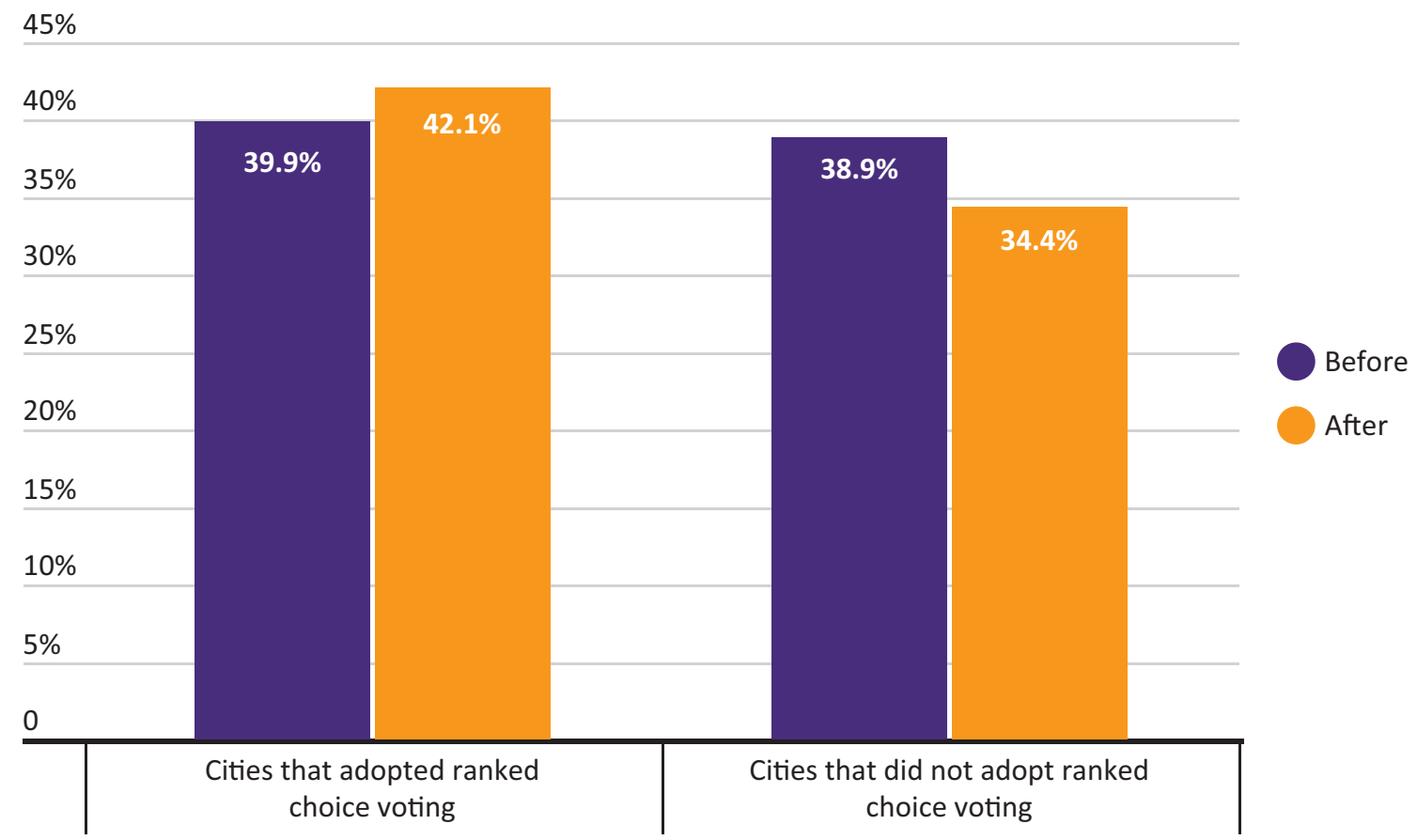

Figure 2. Percentage of women winning, before and after ranked choice voting in the Bay Area (1995-2014). Source: John et al. (2016).

winning $58 \%$ of mayoral elections and $55 \%$ of city council elections (Table 1).

As of July 2020, women's average representation is eleven points higher in the California city councils elected using ranked choice voting compared to the average of comparison California cities with a population 30,000 or higher, excluding the four treatment cities (Table 2).
Similar discrepancies in representation exist when comparing the four Bay Area city councils elected using ranked choice voting with the seven control Bay Area city councils. In the four treatment cities Women's representation on the city council is ten points higher than the control city councils (Table 3 ).

Table 1. Ranked choice voting outcomes for women in the Bay Area (2010-2019).

\begin{tabular}{lccccrr}
\hline $\begin{array}{l}\text { Jurisdictions Using } \\
\text { Ranked Choice Voting }\end{array}$ & Seats & Candidates & $\begin{array}{c}\text { Women } \\
\text { Candidates }\end{array}$ & $\begin{array}{c}\text { Percentage of } \\
\text { Women Candidates }\end{array}$ & $\begin{array}{c}\text { Women } \\
\text { Winners }\end{array}$ & $\begin{array}{c}\text { Seats Won } \\
\text { by Women }\end{array}$ \\
\hline Berkeley & 16 & 63 & 24 & $38 \%$ & 8 & $50 \%$ \\
Oakland & 22 & 120 & 51 & $43 \%$ & 17 & $77 \%$ \\
San Francisco & 27 & 184 & 65 & $41 \%$ & $61 \%$ & $60 \%$ \\
San Leandro & 10 & 34 & 14 & $38 \%$ & 42 & $56 \%$ \\
Total & 75 & 401 & 154 & & & \\
\hline
\end{tabular}

Source: Lamendola and Terrell (2020b).

Table 2. Comparison of women's representation in California city councils (July 2020).

\begin{tabular}{lrrr}
\hline & Seats & Women & Percentage of Women \\
\hline Bay Area cities using ranked choice voting & 34 & 16 & $47 \%$ \\
Comparison CA cities with 30,000 + residents & 1,298 & 472 & $36 \%$ \\
\hline
\end{tabular}

Table 3. Comparison of women's representation in the Bay Area (July 2020).

\begin{tabular}{lccr}
\hline & Seats & Women & Percentage of Women \\
\hline Bay Area cities using ranked choice voting & 34 & 16 & $47 \%$ \\
Bay Area control cities & 49 & 18 & $37 \%$ \\
\hline
\end{tabular}


4.2.3. Women's Representation in All Ranked Choice Elections (2010-2019)

Over the past decade, jurisdictions in the U.S. that adopted and implemented ranked choice voting have seen encouraging results for the representation of women traditionally underrepresented at every level of American politics.

Between 2010 and 2019, women won 48\% of the seats elected by ranked choice voting across the 19 municipalities using the voting system (Table 4).

As of January 2021, 13 U.S. cities used ranked choice voting to elect their mayors; women serve as mayors in six of these cities, making up $46 \%$ of ranked choice elected mayors. Comparatively, in U.S. control cities with a population of 30,000 or more, women make up only $23 \%$ of mayors (Figure 3 ).

\subsubsection{Women's Representation in Ranked Choice Elections (November 2020)}

Elections held in November 2020, also had higher than average outcomes for women candidates. Six jurisdictions used ranked choice voting for local elections in November 2020, women made up 39\% of the candidates on ranked choice ballots. Women won $42 \%$ of the seats elected with ranked choice voting, giving women a success rate of $27 \%$ compared to men's success rate of $23 \%$ (Table 5).

Table 4. Outcomes for women candidates in U.S. ranked choice elections (2010-2019).

\begin{tabular}{|c|c|c|c|c|c|c|c|c|}
\hline \multicolumn{2}{|c|}{$\begin{array}{l}\text { Jurisdictions Using Ranked } \\
\text { Choice Voting }\end{array}$} & \multirow{2}{*}{$\frac{\text { Races }}{16}$} & \multirow{2}{*}{$\frac{\text { Seats }}{16}$} & \multirow{2}{*}{$\frac{\text { Candidates }}{63}$} & \multirow{2}{*}{$\begin{array}{c}\begin{array}{c}\text { Women } \\
\text { Candidates }\end{array} \\
24\end{array}$} & \multirow{2}{*}{$\begin{array}{c}\text { Percentage of } \\
\text { Women Candidates } \\
38 \%\end{array}$} & \multirow{2}{*}{$\begin{array}{r}\text { Women } \\
\text { Winners } \\
8\end{array}$} & \multirow{2}{*}{$\begin{array}{c}\begin{array}{c}\text { Seats Won } \\
\text { by Women }\end{array} \\
50 \%\end{array}$} \\
\hline Berkeley & CA & & & & & & & \\
\hline Oakland & CA & 22 & 22 & 120 & 51 & $43 \%$ & 17 & $77 \%$ \\
\hline San Francisco & CA & 27 & 27 & 184 & 65 & $35 \%$ & 11 & $41 \%$ \\
\hline San Leandro & CA & 10 & 10 & 34 & 14 & $41 \%$ & 6 & $60 \%$ \\
\hline Telluride & $\mathrm{CO}$ & 3 & 3 & 9 & 1 & $11 \%$ & 1 & $33 \%$ \\
\hline Cambridge & MA & 10 & 75 & 168 & 56 & $33 \%$ & 32 & $43 \%$ \\
\hline Takoma Park & MD & 5 & 5 & 15 & 6 & $40 \%$ & 3 & $60 \%$ \\
\hline Portland & $\mathrm{ME}$ & 3 & 3 & 22 & 3 & $14 \%$ & 1 & $33 \%$ \\
\hline Eastpoint & MI & 1 & 2 & 4 & 2 & $50 \%$ & 1 & $50 \%$ \\
\hline Minneapolis & $\mathrm{MN}$ & 30 & 32 & 158 & 38 & $24 \%$ & 12 & $38 \%$ \\
\hline St. Louis Park & $\mathrm{MN}$ & 1 & 1 & 3 & 1 & $33 \%$ & 0 & $0 \%$ \\
\hline St. Paul & $\mathrm{MN}$ & 16 & 16 & 75 & 29 & $39 \%$ & 8 & $50 \%$ \\
\hline Buncombe & NC & 1 & 1 & 3 & 2 & $67 \%$ & 0 & $0 \%$ \\
\hline Cumberland & $\mathrm{NC}$ & 1 & 1 & 3 & 1 & $33 \%$ & 1 & $100 \%$ \\
\hline Rowan & NC & 1 & 1 & 3 & 1 & $33 \%$ & 1 & $100 \%$ \\
\hline Las Cruces & NM & 3 & 3 & 17 & 7 & $41 \%$ & 2 & $67 \%$ \\
\hline Santa Fe & NM & 4 & 4 & 14 & 4 & $29 \%$ & 3 & $75 \%$ \\
\hline Payson & UT & 1 & 3 & 5 & 1 & $20 \%$ & 1 & $33 \%$ \\
\hline Vineyard & UT & 1 & 2 & 7 & 2 & $29 \%$ & 1 & $50 \%$ \\
\hline Total & - & 156 & 227 & 907 & 308 & $34 \%$ & 109 & $48 \%$ \\
\hline
\end{tabular}

Source: Lamendola and Terrell (2020b).

Gender of Mayors Elected with Ranked Choice Voting

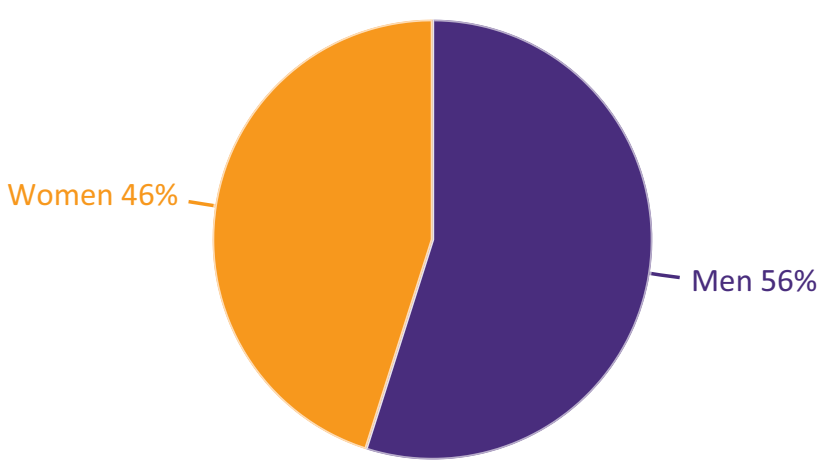

Gender of Mayors in Control Cities (population 30,000+)

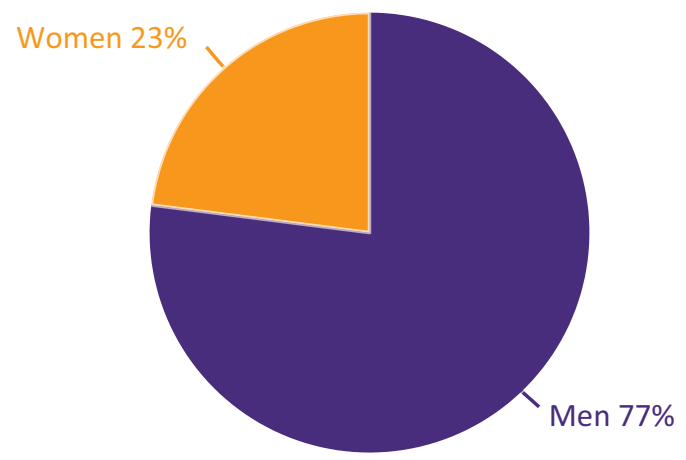

Figure 3. Comparison of women's mayoral representation in the U.S. (January 2021). 
Table 5. Outcomes for women candidates in U.S. ranked choice elections in 2020.

\begin{tabular}{|c|c|c|c|c|c|c|c|c|}
\hline \multicolumn{2}{|c|}{$\begin{array}{l}\text { Jurisdictions Using Ranked } \\
\text { Choice Voting }\end{array}$} & \multirow{2}{*}{$\frac{\text { Races }}{2}$} & \multirow{2}{*}{$\frac{\text { Seats }}{2}$} & \multirow{2}{*}{$\frac{\text { Candidates }}{6}$} & \multirow{2}{*}{$\begin{array}{c}\begin{array}{c}\text { Women } \\
\text { Candidates }\end{array} \\
2\end{array}$} & \multirow{2}{*}{$\begin{array}{c}\begin{array}{c}\text { Percentage of } \\
\text { Women Candidates }\end{array} \\
50 \%\end{array}$} & \multirow{2}{*}{$\begin{array}{c}\text { Women } \\
\text { Winners } \\
2\end{array}$} & \multirow{2}{*}{$\begin{array}{c}\text { Seats Won } \\
\text { by Women } \\
100 \%\end{array}$} \\
\hline Benton & OR & & & & & & & \\
\hline Eastpointe & MI & 1 & 1 & 3 & 2 & $66 \%$ & 1 & $100 \%$ \\
\hline Berkeley & $\mathrm{CA}$ & 4 & 4 & 14 & 4 & $29 \%$ & 1 & $25 \%$ \\
\hline San Francisco & CA & 5 & 5 & 26 & 8 & $31 \%$ & 2 & $40 \%$ \\
\hline Oakland & $\mathrm{CA}$ & 9 & 9 & 37 & 16 & $43 \%$ & 3 & $33 \%$ \\
\hline Portland & ME & 3 & 3 & 11 & 5 & $45 \%$ & 1 & $33 \%$ \\
\hline- & ME & 2 & 2 & 9 & 4 & $44 \%$ & 1 & $50 \%$ \\
\hline Total & - & 26 & 26 & 106 & 41 & $39 \%$ & 11 & $42 \%$ \\
\hline
\end{tabular}

\section{Conclusion: Electoral Systems Matter, Especially for Women}

In her 1995 book on proportional representation in the U.S., Katherine Barber concisely argues "electoral systems have political consequences" (Barber, 1995, p. 81). The U.S.' plurality-winner, geographically-based election systems are a holdover from English colonial rule, which has persisted for over 200 years despite its continued failures to adequately represent the true diversity of opinion, race, class, gender and age in elected bodies.

Although academic research on the topic of minority representation under ranked choice voting is slowly expanding, there is still more to do on the impact for women candidates, who continue to be underrepresented at every level of American politics. Original research in this article has highlighted the strong correlation between the adoption of ranked choice voting at the local level and outcomes for women and minorities; but it must also be built upon in the future by experts in the field. The findings in this article should be re-examined and re-visited as more jurisdictions in the U.S. implement ranked choice voting and the sample size increases. Suggested areas that require further research should include a focused study of single- and multi-seat ranked choice voting in the U.S., and the extent to which each variant improves descriptive representation.

Jeannette Rankin, the first woman elected to Congress and a proponent of multi-seat districts and ranked choice voting, once said “you can't have progress, without choice" (Chall, 1974, p. 29). Maintaining the political status quo limits the choices of voters and citizens, hindering not only diverse representation, but progress toward a more perfect union.

\section{Acknowledgments}

The authors gratefully acknowledge all RepresentWomen staff and interns who aided with the collection of data on women's representation in ranked choice elections in the U.S. The authors also thank the three reviewers for their constructive comments and feedback on the article.

\section{Conflict of Interests}

The authors declare no conflict of interests.

\section{References}

Amy, D. J. (1993). Real choices, new voices: The case for proportional representation elections in the United States. New York, NY: Columbia University Press.

Amy, D. J. (1996). The forgotten history of the single transferable vote in the United States. Journal of Representative Democracy, 34(1), 13-20.

Anest, J. (2009). Ranked choice voting: A path toward a more integral politics. Journal of Integral Theory, 4(3), 23-40.

Barber, K. L. (1995). Proportional representation and electoral reform in Ohio. Columbus, $\mathrm{OH}$ : Ohio State University Press.

Barber, K. L. (2000). A right to representation: proportional election systems for the twenty-first century. Columbus, $\mathrm{OH}$ : Ohio State University Press.

Benade, G., Buck, R., Duchin, M., Gold, D., \& Weighill, T. (in press). Ranked choice voting and minority representation. MGGG Redistricting Lab. Retrieved from https://mggg.org/uploads/STV-POC.pdf

Bennett, S., \& Lundie, R. (2007). Australian electoral systems. Parliament of Australia Politics and Public Administration Section. Retrieved from https:// www.aph.gov.au/About_Parliament/Parliamentary_ Departments/Parliamentary_Library/pubs/rp/ RP0708/08rp05

Brown, N., \& Lemi, D. (2020). “Life for me ain't been no crystal stair": Black Women candidates and the Democratic Party. Boston University Law Review, 100(5), 1613-1687.

Burnham, R. (1997). Reform, politics and race in Cincinnati: Choice voting and black voters in Cincinnati. Journal of Urban History, 23(2), 131-163.

Burnham, R. (2013). Women and reform in Cincinnati: Responsible citizenship and the politics of 'good government' 1924-1955. Ohio Valley History, 13(2), 48-69.

Center for American Women and Politics. (2021). Women in elective office 2021. Eagleton Institute of 
Politics. Retrieved from https://cawp.rutgers.edu/ women-elective-office-2021

Chall, M. (1974). Jeannette Rankin. Calisphere. Retrieved from http://content.cdlib.org/view?docld= kt758005dx\&brand=calisphere

Dittmar, K. (2020). Advancing women's political power in the next century. Boston University Law Review, 100, 1665-1687.

Doctor, J., \& Landsman, T. (2017). Proportional representation in New York City: New York City's experiment with proportional representation and multiparty democracy. FairVote. Retrieved from https:// www.fairvote.org/new_york_s_proportional_ representation_experiment_demonstrates_ potential_of_fair_representation

Donovan, T., Tolbert, C., \& Gracey, K. (2016). Campaign civility under preferential and plurality voting. Electoral Studies, 42, 157-163.

Fox, R. (1997). Gender dynamics in Congressional elections. Thousand Oaks, CA, London and New Delhi: SAGE Publications.

Fox, R., \& Lawless, J. (2010). If only they'd ask: Gender recruitment and political ambition. The Journal of Politics, 72(2), 310-326.

John, S., Smith, H., \& Zach, E. (2018). The alternative vote: Do changes in single-member voting systems affect descriptive representation of women and minorities? Electoral Studies, 54, 90-102.

John, S., Smith, H., Zack, E., Terrell, C. R., Whittaker, M., \& Richie, R. (2016). The impact of ranked choice voting on representation: How ranked choice voting affects women and people of color candidates in California. Takoma Park, MD: RepresentWomen. Retrieved from https://fairvote.box.com/s/ vtp8x7z2n2g6vff1gndqt4m5Isloo364

Kolesar, R. J. (1996). Communism, race and the defeat of proportional representation in Cold War America. John Carroll University. Retrieved from https:// www.fairvote.org/communism_race_and_the defeat_of_proportional_representation_in_cold_ war_america

Lamendola, C., \& Terrell, C. R. (2020a). Gender parity index: The status of women's representation in the suffrage centennial. Takoma Park, MD: RepresentWomen. Retrieved from https://fairvote.box.com/s/ zec83ir42w87xrlgbuunwprzm28b9wzb

Lamendola, C., \& Terrell, C. R. (2020b). In ranked choice elections, women win. Takoma Park, MD: RepresentWomen. Retrieved from https://fairvote.box.com/s/ 338stvaoz3urud062ym5kt8r44927oze

Lawless, J. L., \& Fox, R. L. (2005). It takes a candidate: Why women don't run for office. Cambridge: Cambridge University Press.

Malveaux, J. (2018). No more 'wait your turn' politics. Richmond Free Press. Retrieved from http:// richmondfreepress.com/news/2018/jul/13/nomore-wait-your-turn-politics

McGinn, E. (2020). Effect of instant run-off voting on par- ticipation and civility. Sydney: University of Technology Sydney.

Novoselic, K. (2015). A brief history of ranked choice voting. FairVote. Retrieved from https://www.fairvote. org/a-brief-history-of-ranked-choice-voting

Ochoa, C., \& Cheung, G. (2020). Back to the future: What New York's democracy experiment of the 1930s says about today. The Fulcrum. Retrieved from https://thefulcrum.us/voting/ranked-choice-votingin-new-york

Osborn, T. (2012). How women represent women: Political parties, gender, and representation in the state legislatures. Oxford: Oxford University Press.

Piscopo, J. (2020). What does it take to get women elected? Boston Review. Retrieved from http://bostonreview.net/forum/jennifer-m-piscopowhat-does-it-take-get-women-elected

Piscopo, J., Krook, M., \& Franceschet, S. (2012). The impact of gender quotas. Oxford: Oxford University Press.

Reilly, B. (2002). Electoral systems for divided societies. Journal of Democracy, 13(2), 156-170.

Richie, R. (2004). Instant runoff voting: What Mexico (and others) could learn. Election Law Journal, 3(3), 501-512.

Rule, W. (1987). Electoral systems, contextual factors and women's opportunity for election to parliament in twenty-three democracies. The Western Political Quarterly, 40(3), 477-498.

Rule, W. (1994). Women's underrepresentation and electoral systems. Political Science and Politics, 27(4), 689-692.

Schwindt-Bayer, L., Malecki, M., \& Crisp, B. F. (2010). Candidate gender and electoral success in single transferable vote systems. British Journal of Political Science, 40, 693-709.

Sellers, J. (2019). Election law and white identity politics. Fordham Law Review, 87(4), 1515-1576.

Supreme Court of Ohio. (1912). Vote on amendments submitted to the people by the Convention. Columbus, $\mathrm{OH}$ : Supreme Court of Ohio.

Teele, D. L., Kalla, J., \& Rosenbluth, F. (2018). The ties that double bind: Social roles and women's underrepresentation in politics. American Political Science Review, 112(3), 525-541.

Terrell, C. R., \& Reilly, M. (2020a). Achieving gender parity: Systems strategies around the world. Takoma Park, MD: RepresentWomen. Retrieved from https://fairvote.app.box.com/s/1jjyvjptt3dmeaeypw jpbmqzquacpiqi

Terrell, C. R., \& Reilly, M. (2020b). PACs and donors: Agents of change for women's representation. Takoma Park, MD: RepresentWomen. Retrieved from https://fairvote.app.box.com/s/19kj1faa8ofy9vy69 cq09s42f3hanq0d

Thomas, J. P. (2017). The history of FairVote: The founding years. FairVote. Retrieved from https:// www.fairvote.org/the_history_of_fairvote_the_ founding_years 
Thomas, S., \& Wilcox, C. (2014). Women and elective office: Past, present, and future (3rd ed.). Oxford: Oxford University Press.

Thomsen, D., \& King, A. S. (2020). Women's representation and the gendered pipeline to power. American Political Science Review, 114(4), 989-1000.
Wolbrecht, C. (2000). The politics of women's rights. Princeton, NJ: Princeton University Press.

Zimmerman, J. (1994). Alternative voting systems for representative democracy. Political Science \& Politics, 27(4), 674-677.

\section{About the Authors}

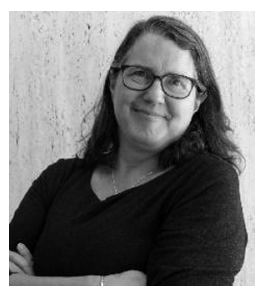

Cynthia Richie Terrell is the Founder and Executive Director of RepresentWomen, a nonprofit research and advocacy hub studying the barriers women face in U.S. politics and potential solutions for achieving gender-balanced political representation. Terrell has been published in many news outlets including: The Washington Post, The New York Times, The Baltimore Sun, The Hill, The Fulcrum, The Pittsburgh Post Gazette and Ms Magazine; and was a contributor in the 2020 book The Best Candidate: Presidential Nomination in Polarized Times.

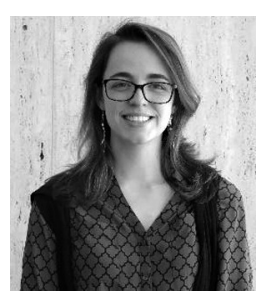

Courtney Lamendola is the Research Director of RepresentWomen. Her research projects during her time with RepresentWomen have included the 2020 Gender Parity Index, the 2020 Ranked Choice Voting Report, and a chapter on women and the presidency in the 2020 book, The Best Candidate: Presidential Nomination in Polarized Times. Lamendola earned an MA in International Relations and Economics from Johns Hopkins SAIS, and a BA in Political Science from Providence College.

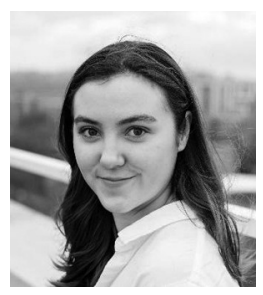

Maura Reilly is the Outreach and Communications Coordinator for RepresentWomen, where she previously worked as a Research Fellow. Her research projects for RepresentWomen include: the 2020 PAC Report, the 2020 International Report, and the 2020 Tribal Nations Brief. Reilly earned a MA (Honours) in Social Anthropology from the University of St Andrews. She has also had an article on the International Women's March published in Ethnographic Encounters, an undergraduate academic journal. 